\title{
Fiber dimension of Makurdi grown Musa balbisiana Colla parts and their suitability in paper production
}

\author{
David Oriabure Ekhuemelo*, Vivian Ojoma Aidoko and Veronica Eyakamo Abu \\ Department of Forest Production and Products, Federal University of Agriculture Makurdi, Nigeria \\ *Corresponding Author: davidekhuemelo@gmail.com
}

\begin{abstract}
This study evaluated the fibre morphology of Musa balbisiana leaf, stalk and stem portions for pulp and paper production. Samples of Musa balbisiana portions were prepared and macerated in equal volume of glacial acetic acid and hydrogen peroxide in ratio 1:1. Twenty cellulose fibres from each portion were randomly selected using Reichert visopan microscope to determine the physical fibre morphology while the derived fibre indices were calculated. Data collected were subjected to one way Analysis of Variance (ANOVA). Follow up tests carried out using Duncan Multiple Range Test (DMRT). Results showed that means of fibre length, fibre diameter, cell wall thickness and lumen width ranged between 1.35 and $2.46 \mathrm{~mm}, 16.46$ and $33.34 \mu \mathrm{m}, 7.58$ and $24.99 \mu \mathrm{m}$, and 3.54 and $3.56 \mu \mathrm{m}$, respectively. The mean values of fibre length of Musa balbisiana leaf and stalk were not significant but were significantly different from the mean values of the stem at $\mathrm{p}<0.05$. The mean values of felting rate, elasticity coefficient, rigidity coefficient, Runkel ratio and F factor ranged from 84.47 to $142.43,48.94$ to $76.07 \%, 11.96$ to $25.53 \%, 0.34$ to 1.12 and 433.50 to 627.22 , respectively. The leaf stalk of Musa balbisiana had the best Runkel ratio of 0.34 while Musa balbisiana stem had the best fibre length of $2.46 \mathrm{~mm}$. Results further showed that while fibre length of stalk and stem portions of Musa balbisiana were long fibres, the leaf portion was short fibre. Runkel ratios of Musa balbisiana stalk, Leaf and stem were very good, good and poor, respectively while the Leaf, stalk and stem were elastic, high elastic and rigid fibre, respectively. In conclusion, Musa balbisiana has proved to be a very suitable non-wood, agricultural based material for pulp and paper production.
\end{abstract}

Keywords: Musa balbisiana, Non-wood, Pulp, Paper, Fibre morphology.

\section{INTRODUCTION}

Pulp and paper are very versatile in nations' educational, social and industrial development. The consumption of paper was considered to upsurge from 316 million tons in 1999 and 351 million tons in 2005, to about 425 million tons by the year 2010 (García et al., 2008). This huge demand is faced with global challenge of scarce wood raw material which has been the main basis of pulp and paper production.

In search of new raw materials as substitute to wood for pulp and paper making and to overcome the shortage and the increasing demand of and paper products, non-woody plants are been considered by researchers as promising sources to paper production due to their numerous merit as short growth cycles, modest irrigation and low lignin content which are capable to reducing the energy and chemicals used in pulping process (Brindha et al., 2012).

There is growing interest in the use of non-wood such as annual plants and agricultural residues as a raw material for pulp and paper. El-Sakhawy et al. (1996) reported that non-wood raw materials account for less than $10 \%$ of the total pulp and paper production worldwide. Non-wood lingo-cellulosic raw materials commonly utilized for cellulose production are allocated in $44 \%$ straw, $18 \%$ sugarcane bagasse, $14 \%$ reeds, $13 \%$ bamboo and $11 \%$ others (Sridach, 2010). The utilization of non-wood for pulp and paper production mostly takes place in countries with a scarcity of wood like China and India (Oinonen \& Koskivirta, 1999). China uses more than half of the non-wood pulp produced worldwide (Hammett et al., 2001).

Paper was initially produced from non-woody plants. Presently, the use of non-wood pulp has been included in the grades of paper like printing and writing papers, liner boards, corrugated medium, newsprint, tissue and specialty paper (Hurter, 2001). Utilization of non-wood fibres is an excellent way to producing pulp and paper in comparison to the clear-cutting of rain forests or primeval forests. Non-wood is very beneficial plant sources fibre resources because of their fast annual growth and the reduced quantity of lignin content in them which bind their fibres together. Non-wood pulp is also important because it can be produced at reduced temperatures with lesser chemical charges. Non-wood pulps are more easily refined compared to wood pulps. Additionally, non-wood utlization can give added value income to farmers involved in production of food crops or cattle rearing (Rousu et al., 2002; Rodriguez et al., 2007; Kissinger et al., 2007).

The function of pulp and paper products in modern society and with the ever increasing level of literacy is 
overwhelming. Paper occupies position of almost inconceivable implication in both developed and developing nations like Nigeria (Onilude, 2011). At present, over 95\% of paper products are produced from wood, while the balance consists of fibrous materials, such as agricultural wastes.

Musa balbisiana Colla is a wild species of banana. It formed the basis of many edible bananas by its hybridization with Musa acuminate (Colla, 1820). Musa balbisiana is native to eastern South Asia, northern Southeast Asia, and southern China. It was first scientifically described in 1820 by an Italian botanist Luigi Aloysius Colla. It grows lush leaves in clumps with a more upright habit than most cultivated bananas. They are regarded inedible because of the seeds they contain. It may be assumed that wild bananas were cooked and eaten otherwise agriculturalists would not have developed the cultivated banana (Deka et al., 2018). Musa balbisiana is associated with tolerance to abiotic stresses.

In Makurdi, there is an abundance of Musa balbisiana. This species of banana grows profusely in Makurdi and is mostly eaten by the locals with little or no market value. Musa balbisiana has not been assessed for pulp and paper production in this area. Therefore, the aim of this study was to assess pulp and paper potentials of Musa balbisiana grown in Makurdi, Benue State, Nigeria.

\section{MATERIALS AND METHODS}

\section{Study area}

The study was conducted at the Federal University of Agriculture, Makurdi, Benue State. Benue State is generally regarded as the 'Food basket' of Nigeria, because its ecology supports extensive arable cropping and livestock production as well as fruit, palm, grains, legumes, root and tuber production. Makurdi lies between Latitude $7^{\circ} 38^{\prime}$ and $7^{\circ} 50^{\prime}$ North, and Longitude $8^{\circ} 24^{\prime}$ and $8^{\circ} 38^{\prime}$ East. The town lies within the guinea savannah vegetation zone and experiences two distinct seasons, the wet/rainy season and the dry/summer season. The rainy season lasts from April to October with annual rainfall in the range of 1000-2000 mm. The dry season begins in November and ends in March. The temperatures fluctuate between $23-37{ }^{\circ} \mathrm{C}$ in the year (Ministry of Information \& Orientation, 2012).

\section{Collection and preparation of samples}

The stem, leaf and stalk were collected from matured Musa balbisiana plant, cut into chips and air dried for two weeks to remove the moisture in it.

\section{Determination of fibre characteristics}

Fibre characteristics determination was carried out at the Forest Research Institute of Nigeria (FRIN), Ibadan. Each sample was prepared into slivers of about $1 \mathrm{~cm} \times 2 \mathrm{~mm} \times 2 \mathrm{~mm}$. The slivers were macerated in equal volume of glacial acetic acid and hydrogen peroxide (1:1) inside an oven at about $100^{\circ} \mathrm{C}$ for 2 hours. The resultant solution was agitated to separate cellulose fibre into individual fibres. Slides of macerated fibre were inserted unto stage micrometer mounted on a Zeiss light microscope (Standard 25) under 80×. The microscopy was achieved in agreement with the ASTM D1413-48 of 1983 and ASTM D1413-61 method of 2007. Twenty full length fibres were randomly selected from each representative samples to determine fibre length, fibre diameter, cell wall thickness and lumen width following the approach employed by Jorge (1999) when at least 20 fibres per slide were measured to keep error below 5\% for a $95 \%$ confidence level. Derived fibre indices were calculated from measured fibre morphology as follows:

$$
\begin{aligned}
& \mathrm{Fr}=\frac{\mathrm{FL}}{\mathrm{FD}} \\
& \mathrm{EC}(\%)=\frac{\mathrm{LW}}{\mathrm{FD}} \times 100 \\
& \mathrm{RC}(\%)=\frac{\mathrm{CWT}}{\mathrm{FD}} \times 100 \\
& \mathrm{RR}=\frac{\mathrm{CWT} \times 2}{\mathrm{LW}} \\
& \mathrm{Ff}=\frac{\mathrm{FL}}{\mathrm{CWT}} \times 100
\end{aligned}
$$

Where, Fr = Felting rate; FL= Fibre length; FD = Fibre diameter; EC = Elasticity coefficient; LW = Lumen Width; $\mathrm{RC}=$ Rigidity coefficient CWT $=$ Cell wall thickness; $\mathrm{RR}=$ Runkel ratio; $\mathrm{Ff}=\mathrm{F}$ factor.

\section{Data analysis}

Data of the study were subjected to one way analysis of variance (ANOVA) to determine the significant effects of different portion on the properties. Follow up test was carried out using Duncan Multiple Range Test (DMRT) where significant differences exist.

\section{RESULT}

Table 1 shows the means of Fibre length, Fibre diameter, Lumen width and cell wall thickness of Musa balbisiana 
at leaf, stalk and stem portions. The means of fibre length, fibre diameter, lumen width and cell wall thickness ranged from 1.35-2.4 $6 \mathrm{~mm}, 14.69-33.34 \mu \mathrm{m}, 7.58 \mu \mathrm{m} 24.99$ and 3.54-4.18 $\mu \mathrm{m}$, respectively. The result also reveals that the means of fibre length of leaf and stalk were not significantly different from each other but differ significantly from the mean of the stem portion at $\mathrm{p}<0.05$. The result further showed that means of fibre diameter, lumen width and cell wall thickness of leaf and stem portions did not differ significantly from the mean of the stalk portion at $\mathrm{p}<0.05$.

\begin{tabular}{lllr} 
Table 1. Mean Values of Fibre Characteristics of Musa balbisiana & Colla (Leaf, leaf stalk and stem). \\
\hline Fiber characteristics & Plant portion & N & Mean \pm SD \\
\hline \multirow{4}{*}{ Fibre length $(\mathrm{mm})$} & Leaf & 20 & $1.35 \pm 0.84^{\mathrm{a}}$ \\
& Stalk & 20 & $1.79 \pm 0.35^{\mathrm{a}}$ \\
& Stem & 20 & $2.46 \pm 1.59^{\mathrm{b}}$ \\
& Total & $\mathbf{6 0}$ & $\mathbf{1 . 8 6} \pm \mathbf{1 . 1 4}$ \\
\hline \multirow{4}{*}{ Fibre Diameter $(\mu \mathrm{m})$} & Leaf & 20 & $16.76 \pm 4.80^{\mathrm{a}}$ \\
& Stalk & 20 & $33.34 \pm 7.35^{\mathrm{b}}$ \\
& Stem & 20 & $14.69 \pm 6.50^{\mathrm{a}}$ \\
& Total & $\mathbf{6 0}$ & $\mathbf{2 1 . 5 9 \pm \mathbf { 1 0 . 4 5 }}$ \\
\hline & Leaf & 20 & $9.68 \pm 2.89^{\mathrm{a}}$ \\
& Stalk & 20 & $24.99 \pm 5.03^{\mathrm{b}}$ \\
& Stem & 20 & $7.58 \pm 3.86^{\mathrm{a}}$ \\
& Total & $\mathbf{6 0}$ & $\mathbf{1 4 . 0 8 \pm 8 . 7 7}$ \\
\hline & Leaf & 20 & $3.54 \pm 1.38^{\mathrm{a}}$ \\
& Stalk & 20 & $4.18 \pm 2.35^{\mathrm{a}}$ \\
& Stem & 20 & $3.56 \pm 1.46^{\mathrm{a}}$ \\
& Total & $\mathbf{6 0}$ & $\mathbf{3 . 7 6} \pm \mathbf{1 . 7 8}$ \\
\hline
\end{tabular}

Table 2 shows the means of felting rate, elasticity coefficient, rigidity coefficient, Runkel ratio and $\mathrm{F}$ factor of Musa balbisiana at leaf, stalk and stem portions. The means of felting rate, elasticity coefficient, rigidity coefficient, Runkel ratio and $\mathrm{F}$ factor varied from 57.23-142, 48.94-76.07 \%, 11.96-25.53 \%, 0.34-1.12, 433.50-627.22, respectively. Means of felting rate of the leaf and stalk are not significantly different from each other but differ significantly from the mean of the stem portion at $\mathrm{p}<0.05$. However, means of elasticity coefficient, rigidity coefficient and Runkel ratio of Musa balbisiana portions were significantly at $\mathrm{p}<0.05$. On the contrary, means of $\mathrm{F}$ factor of Musa balbisiana leaf, stalk and stem portions are not significantly different $(\mathrm{p}<0.05)$.

\begin{tabular}{lllr}
\multicolumn{3}{l}{ Table 2. Mean Values of Fibre Derivatives of Musa balbisiana Colla (Leaf, leaf stalk and stem). } \\
\hline Fibre derivatives & Plant portion & N & Mean \pm SD \\
\hline \multirow{4}{*}{ Felting rate } & Leaf & 20 & $84.47 \pm 54.65^{\mathrm{a}}$ \\
& Stalk & 20 & $57.23 \pm 21.30^{\mathrm{a}}$ \\
& Stem & 20 & $142.43 \pm 74.99^{\mathrm{b}}$ \\
& Total & $\mathbf{6 0}$ & $\mathbf{9 4 . 7 1} \pm \mathbf{6 4 . 8 2}$ \\
\hline \multirow{5}{*}{ Elasticity coefficient $(\%)$} & Leaf & 20 & $57.89 \pm 10.09^{\mathrm{b}}$ \\
& Stalk & 20 & $76.07 \pm 10.01^{\mathrm{c}}$ \\
& Stem & 20 & $48.94 \pm 9.41^{\mathrm{a}}$ \\
& Total & $\mathbf{6 0}$ & $\mathbf{6 0 . 9 7} \pm \mathbf{1 4 . 9 4}$ \\
\hline \multirow{5}{*}{ Rigidity coefficient $(\%)$} & Leaf & 20 & $21.06 \pm 5.04^{\mathrm{b}}$ \\
& Stalk & 20 & $11.96 \pm 5.01^{\mathrm{a}}$ \\
& Stem & 20 & $25.53 \pm 4.70^{\mathrm{c}}$ \\
& Total & $\mathbf{6 0}$ & $\mathbf{1 9 . 5 2} \pm \mathbf{7 . 4 7}$ \\
\hline \multirow{5}{*}{ Runkel ratio } & Leaf & 20 & $0.78 \pm 0.34^{\mathrm{b}}$ \\
& Stalk & 20 & $0.34 \pm 0.20^{\mathrm{a}}$ \\
& Stem & 20 & $1.12 \pm 0.44^{\mathrm{c}}$ \\
& Total & $\mathbf{6 0}$ & $\mathbf{0 . 7 5} \pm \mathbf{0 . 4 6}$ \\
\hline & Leaf & 20 & $633.50 \pm 342.659^{\mathrm{a}}$ \\
F Factor & Stalk & 20 & $620.25 \pm 448.11^{\mathrm{a}}$ \\
& Stem & 20 & $627.22 \pm 428.78^{\mathrm{a}}$ \\
& Total & $\mathbf{6 0}$ & $\mathbf{5 6 0 . 3 2} \pm \mathbf{4 1 2 . 1 5}$ \\
\hline
\end{tabular}

Table 3 shows the sustainability of Musa balbisiana portions for pulp and paper making. While the fibre length of stalk and stem portions have long fibres, the leaf portion had short fibre. The result also showed that the Runkel ratios of Musa balbisiana stalk, Leaf and stem were very good, good and poor respectively. The summary of the elasticity coefficient of Musa balbisiana Leaf, leaf stalk and stem portions is presented in table 4. The result revealed that Musa balbisiana Leaf, stalk and stem were classified as elastic, high elastic and rigid fibre, respectively. 
Table 3. Sustainability of Musa balbisiana Colla (Leaf, leaf stalk and stem) for pulp and paper making based on fibre length and Runkel ratio.

\begin{tabular}{lcrlr}
\hline \multirow{2}{*}{ Species } & \multicolumn{2}{c}{ Fibre length } & \multicolumn{2}{c}{ Runkel ratio } \\
\cline { 2 - 5 } & Value & Fibre class & Value & Ranking \\
\hline Leaf & 1.35 & short & 0.78 & good \\
Stalk & 1.79 & long & 0.34 & very good \\
Stem & 2.46 & long & 1.12 & Poor \\
\hline
\end{tabular}

Table 4. Summary of the Elasticity Coefficient of Musa balbisiana Colla Leaf, leaf stalk and stem Portions.

\begin{tabular}{lcr}
\hline \multirow{2}{*}{ Species } & \multicolumn{2}{c}{ Elasticity coefficient $(\%)$} \\
\cline { 2 - 3 } & Value & Types of fibre \\
\hline Leaf & 57.89 & Elastic \\
Stalk & 76.07 & High elastic \\
Stem & 48.94 & Rigid fibre \\
\hline
\end{tabular}

\section{DISCUSSION}

\section{Fibre morphology of Musa balbisiana}

Fibre length

The fibre length of Musa balbisiana in this study ranged from $1.35 \mathrm{~mm}$ in the leaf to $2.46 \mathrm{~mm}$ in the stem with the mean of $1.86 \mathrm{~mm}$. Fibres length below $1.60 \mathrm{~mm}$ are classified as short while those above $1.60 \mathrm{~mm}$ in length is said to be long fibres. It therefore implies that the mean fibre length of Musa balbisiana leaf is long fibre. Qgunkunle \& Oladele (2008) reported fibre length of less than $1.60 \mathrm{~mm}$ for 12 Ficus species. Long fibres are preferred for manufacture of paper because they give a more open and less uniform sheet structure (Oluwadare \& Ashimyu, 2007). Short fibres lack formation of good surface content and fibre-fibre bonding (Ogbonnaya et al., 1992). Ademiluyi \& Okeke (1979) reported that the longer the fibre, the higher the tear resistance and the better the quality of the paper produced.

The mean fibre obtained from Musa balbisiana in this study is similar to $1.37 \mathrm{~mm}$ for maize husk and $1.52 \mathrm{~mm}$ for maize stalk reported by Ekhuemelo \& Tor (2013). Goswani et al. (2009) reported an average fibre length of $1.55 \mathrm{~mm}$ for Musa $\times$ paradisiaca L. which is good quality and can be used to produce greaseproof paper. Similarly, Noah (2009) reported fibre length of $1.7 \mathrm{~mm}$ value for bagasse fibre. However, fibre length of Musa balbisiana stem as obtained in this study, is higher than the recommended fibre length for good quality pulp and paper and implies that Musa balbisiana is a good source of raw material for good quality paper.

\section{Fibre diameter}

In this study, Musa balbisiana had fibre dimeter of $14.69 \mu \mathrm{m}$ for stem, $16.76 \mu \mathrm{m}$ for leaf, and $33.34 \mu \mathrm{m}$ for stalk. Fibre diameter has been reported to be related to the molecular and physiological variations occuring in the vascular cambium plus increase in cell walls during the tree growing process (Plomion et al., 2001; Rouge \& Fo, 2007). The values obtained in this study are within the range of 20-40 $\mu \mathrm{m}$ fibre diameters for hardwood fibres reported by (Usta \& Eroghe, 1987). The values are lower compared to some non-wood materials with paper making potential according to Ogbonnaya et al. (1992) and Pahkala (2001). This agrees with the values reported by Oluwadare (2006) for fibre diameter of some Nigerian grown Musa species.

\section{Lumen width}

Average mean lumen width of different parts of Musa balbisiana were $9.68 \mu \mathrm{m}, 24.99 \mu \mathrm{m}$ and $7.58 \mu \mathrm{m}$ for leaf, stalk and stem, respectively. They are higher than that $4.34 \mu \mathrm{m}$ for Musa sapentium L. reported by Osadare \& Udohitinah (1993). Mean fibre lumen width stem values of Musa balbisiana is close to $8.49 \mu \mathrm{m}$ for Sterculia roblonga reported by Osadare \& Udohitinah (1993). The values obtained are generally higher than those reported for similar non wood fibres. Fibre lumen width influence the beating of pulp in the sense that, the larger the fibre lumen width, the better will be the beating of pulp due to the penetration of liquids into vascular spaces of the fibres (Panshin \& De Zeeuw, 1980).

\section{Cell wall thickness}

The result also reveals the mean of cell wall thickness of Musa balbisiana as $3.54 \mu \mathrm{m}$ for leaf, $4.18 \mu \mathrm{m}$ for stalk and $3.56 \mu \mathrm{m}$ for stem, which is higher than the values in Sterculia setigera Delile reported by Oluwadare \& Egbewole (2008). Also, the mean values obtained in this study are lower than $4.34 \mu \mathrm{m}$ for Musa $\times$ sapientum L. reported by Osadare \& Udohitinah (1993). Cell wall thickness influences the specific gravity of fibrous raw materials which in turn has a marked effect on the pulp sheet properties (Colley, 1973). 


\section{Derived fibre morphological indices of Musa balbisiana}

\section{Felting power/Slenderness ratio}

The mean values for felting power of Musa balbisiana were 84.47 for leaf, 57.23 for stalk and 142.43 for stem. These values are within the range of 63.81 for Saccharum officinarum L. (bagasse) and 101.50 for Sterculia setigera reported by Oluwadare \& Egbewole (2008). Felting power is produced by shorter and thicker fibres which in turn reduced tearing resistance drastically. There is positive correlation between the slenderness ratio and folding endurance (Ona et al., 2001). It also affects the flexibility and resistance to rupture of the fibres and paper product made there from (Xu et al., 2006). Felting power has positive effect on strength, tear, and burst, breaking off, double folding resistance according to physical test result of the paper. A slenderness ratio/Felting power of cellulose material that is greater than 33 is regarded a good for pulp and paper making. As result, Musa balbisiana is considered very suitable for pulp and paper production if employed by paper producing industries.

\section{Runkel ratio}

The Runkel ratio for Musa balbisiana was 0.78 in leaf, 0.34 in stalk and 1.12 in stem. The values of the leaf and stalk are within the range of non-wood species as reported by Oluwadare (1998) as 0.78 in Musa textilis Née, 0.76 in Hibiscus cannabinus L., 0.57 for Saccharum officinarum L. reported by (Egbewole et al., 2013) and lower than 0.95 in the bast of Adansonia digitata L. as reported by Oluwadare (1998). Bektas et al. (1999) reported that when Runkel ratio is higher, it would give an equivalent lower paper strength characteristics particularly lower tear, burst, and tensile indexes. This is in line with the finding of Olwudare \& Egbewole (2008) who stated that Runkel ratio was closely related to cell wall thickness and influences paper strength properties. The fibres with Runkel ratios less than 1 are good for paper making because the fibres are more flexible, collapse easily and from a paper with large bonded area hence, the suitability of Musa balbisiana leaf and stalk as a raw material for pulp and paper production.

Runkel ratio determines the suitability of a cellulosic material for pulp and paper production. It is directly affected by cell wall thickness, and not really by lumen diameter (Ona et al., 2001). It is also related to paper conformity, pulp yield and fibre density. Bulkier paper is produced from high Runkel ratio fibres compared to low Runkel ratio fibres. Therefore, the low values obtained in this study imply that Musa balbisiana is essentially important raw material for pulp and paper production.

\section{Elasticity coefficient}

Elasticity coefficient is a further significant standard for evaluating fibre quality. Elasticity coefficient (flexibility ratio) has been classified by Bektas et al. (1991) into four groups of fibres which include: high elastic fibres having elasticity coefficient above 75; elastic fibres with elasticity ratio between 50 and 75 ; rigid fibres containing elasticity ratio between 30 and 50 and highly rigid fibres which comprises elastic below 30 . Based on this classification, elasticity coefficient of all portions of Musa balbisiana are within the high elastic and elastic fibres (57.89-76.07\%) for leaf and stalk, respectively and rigid fibre (48.94\%) for the stem portion. Since rigid fibres do not have efficient elasticity, they are not suitable for paper production and they are used more on fibre plate, rigid cardboard production (Akgul \& Tozkiogu, 2009). Elastic fibres can be stretched making it a suitable raw material for paper making in other to get high resistance.

\section{Rigidity coefficient}

The values of rigidity coefficient obtained from Musa balbisiana were 11.96, 21.06 and $25.53 \%$ for leaf, stalk and stem, respectively. These mean values are within the range reported by (Hus et al., 1975) for juvenile beech wood $(22.95 \%)$ and $27.66 \%$ for Eucalyptus. A high rate of rigidity coefficient affects tensile, tear, burst and double fold resistance of paper negatively (Hus et al., 1975). This implies that paper made from these samples with low rigidity would have less tensile, tear, burst and double fold resistance making it a suitable raw material for pulp and papermaking.

\section{F factor (\%)}

F factor mean values of Musa balbisiana ranged within $433.50 \%$ for leaf $<620.25 \%$ for stalk and $<627.22 \%$ for stem. F factor for beech juvenile wood was found to be $140.38 \%$ and $240.55 \%$ for blank pine juvenile wood (Akgul \& Tozkiogu, 2009). In related studies on softwoods, F factor was found to be $606.66 \%$ for Pinus brutia Ten., $410.34 \%$ and for Cedrus libani A.Rich. F factor for spring wood radial of Pinus pinnaster was determined as $745.40 \%$, spring wood tangent as $69.81 \%$, summer wood radial as $603.9 \%$ and summer wood tangent as $493.0 \%$ (As, 1992). Therefore, it implies that, F factor of Musa balbisiana portions are similar to the ones obtained from softwoods.

\section{CONCLUSION}

Result from fibre morphology and derived fibre indices of Musa balbisiana leaf and stalk have proved that the non 
wood raw material is very suitable for pulp and paper production. The appreciable fibre length and Runkel ratio of Musa balbisiana present it as non-wood, agricultural based material for pulp and paper production. The leaf stalk of Musa balbisiana was best suited for papermaking compared to the stem and leave.

\section{ACKNOWLEDGEMENTS}

The authors are grateful to Mr. Adeniyi Idedayo of Forest Research Institute of Nigeria (FRIN) for his assistance in the cellulose fibre analysis of our samples.

\section{REFRENCES}

Ademiluyi E.O. \& Okeke R.E. (1979). Studies on specific gravity and fibre characteristics of Gmelina arborea in some Nigerian plantations. Nigerian Journal of Science, 13: 231-238.

Akgul M. \& Tozluoglu A. (2009). Some Chemical and Morphological Properties of Juvenile Woods from Beech (Fagus orientalis L.) and Pine (Pinus nigra A.) Plantation. Trends in Apply Science Research, 4(2): 116-125.

As N. (1992). Effect of Pinus pinaster various races on physical, mechanical and technologic properties, (Ph. D. Thesis). Istanbul University.

Bektas I., Tutus A. \& Eroglu H. (1999). A study of the suitability of Calabrian pine (Pinus brutiaten) for pulp and paper manufacture. Turkey Journal of Agriculture and Forestry, 23: 589-599.

Brindha D., Vinodhini S. \& Alarmelumangai K. (2012). Fiber dimension and chemical contents of fiber from Passiflora foetida L. and their suitability in paper production. Science Research Reporter, 2(3): 210-219.

Colla L. (1820). Memorie della Reale Accademia delle Scienze di. Torino, 25: 384-385.

Colley E. (1973). African Timbers; the Properties, Uses and Characteristics of 700 Species. Division of Building Research, C.S.I.R.O. Melbourne, Australia, p. 723.

Deka P., Kashyap A., Sharma D. \& Baruah C. (2018). A Review on Musa Balbisiana Colla. International Journal of Pharmaceutical Science Invention, 7(7): 14-17.

Egbewole Z.T., Omoake P.O. \& Rotowa O.J. (2013). Assessment of Fibre Quality of Saccharum officinarum (sugarcane) Bagasse as a Raw Material for Pulp and Paper Production. In: $38^{\text {th }}$ Annual Conference of Forestry Association of Nigeria (FAN). pp. 352356.

Ekhuemelo D.O. \& Tor K. (2013). Assessment of fibre characteristics and suitability of maize husk and leaf stalk for pulp and paper production. Journal of research in Forestry, Wildlife and Environmental, 5(1): 46-47.

El-Sakhawy M., Lönnberg B., Fahmy Y. \& Ibrahim A.A. (1996). Organosolv Pulping: 3. Ethanol pulping of wheat straw. Cellulose Chemical Technology, 30(2): 161-174.

García M.M., Lopez F., Alfaro A., Ariza J. \& Tapias R. (2008). The use of Tagasaste (Chamaecytisus proliferus) from different origins for biomass and paper production. Bioresources Technology, 99(9): 3451-3457.

Goswani T., Dipul K. \& Rao P.G. (2009). Greaseproof paper from Banana (Musa paradisiaca L.) Pulp Fibre. Indian Journal of Chemical Technology, 15: 457-461.

Hammett A.L., Youngs R.L., Sun X. \& Chandra M. (2001). Non-wood fibre as an alternative to wood fibre in china's pulp and paper industry. Holzforschung, 55(3): 219-224.

Hurter R. W. (2001). Non-wood plant fibre characteristics. Hurter Inc. USA.

Hus S., Tank T. \& Gosksal (1975). Considering Eucalyptus (E. Camadulensis Dhnh) wood which grow in Turkey (in TarsusKarabacak). In: Morphology and opportunity for evaluating semi chemical cellulose in paper industry. Tubitak publication, USA.

Jorge F., Quilhó T. \& Pereira H. (2000). Variability of fibre length in wood and bark in Eucalyptus globulus. IAWA Journal, 21(1): 41-48.

Kissinger M., Fix J. \& Rees W.E. (2007). Wood and non-wood pulp production Comparative ecological footprinting on the Canadian prairies. Ecological Economics, 62 (3-4): 552-558.

Ministry of Information and Orientation (2012). Benue State, Nigeria. International Exchange Annual Report, $350 \mathrm{p}$.

Noah S.A. (2009). Fundamentals of pulp and paper manufacture. Fasco publishers. Ibadan, pp. 11-12.

Ogbonnaya C., Nwalozie M. \& Nwaigbo L.C. (1992). Growth and Wood Properties of Gmelina arborea Seedlings grown under five moisture regimes. American Journal of Botany, 79(2): 128-132.

Oinonen H. \& Koskivirta M. (1999). Special challenges of pulp and paper industry in Asian populated countries, like Indian subcontinent and China. In: Proceedings of the Paperex 99-4 ${ }^{\text {th }}$ International Conference on Pulp and Paper Industry: Emerging Technologies in the Pulp and Paper Industry; December 14-16, 1999; New Delhi, India, pp. 496-498.

Oluwadare A.O. \& Ashimiyu O.S. (2007). The Relationship between Fibre Characteristics and pulp-sheet properties of Leucaena leucocephala (lam) De Wit. Middle-East Journal of Science Resources, 2(2): 63-68.

Oluwadare A.O. \& Egbewole Z.T. (2008). Wood Quality Studies in Plantation Grown Steculia (Steculia setigera) in the Guinea Savannah, Nigeria. Research Journal of Forestry, 2: 22-33.

Oluwadare A.O. (1998). Evaluation of the Fibre and Chemical Properties of some Selected Nigerian Wood and Non-wood species for Pulp Production. Journal of Tropical Forest Research, 14: 110-119.

Oluwadare A.O. (2006). Evaluation of the fibre and chemical properties of selected Nigerian wood and non-wood species for pulp production. pp. 73-79. 
Ona T., Sonoda T., Ito K., Shibata M., Tamai Y., Kojima Y., Ohshima J., Yokota S. \& Yoshizawa N. (2001). Investigation of relationships between cell and pulp properties in Eucalyptus by examination of within-tree variations. Wood Science and Technology, 35: 229-243.

Onilude M.A. (2011). Pulp and paper Industry: A Neglected Goldmine in Nigeria. Inaugural Lecture 2010/2011. University of Ibadan, Nigeria.

Osadare A.O. \& Udohitinah J.S. (1993). Fibre characteristics of some Nigerian raw material for long fibre fibre production. In: Oduwaiye E.A. (Ed.) Forestry for urban and rural development in Nigeria. FAN $23^{\text {rd }}$ Conference, pp. 132-138.

Pahkala L. (2001). Non-wood plants as raw materials for pulp and paper. Agricultural and Food science in Finland, 10(1): 1-101.

Panshin A. \& De Zeeuw C. (1980). Text book of Wood Technology, $4^{\text {th }}$ ed. McGrawth-Hill, New York.

Plomion C., Leprovost G. \& Stokes A. (2001). Wood formation in trees. Plant physiology, 127: 1513-1523.

Qgunkunle A.T.J. \& Oladele F.A. (2008). Structural dimensions and paper making potentials of the wood in some Nigerian species of Ficus L. (Moraceae). Advances in Natural and Applied Sciences, 2(3): 103-111.

Rodriguez A., Moral A., Serrano L., Labidi J. \& Jiimenez L. (2007). Rice straw pulp obtained by using various methods. Bioresources Technology, 99(8): 2881-2886.

Rouge R.M. \& Fo T.M. (2007). Wood density and fibre dimensions of Gmelina arborea in fast growing trees in costa Rica; relation to the growth rate. Sistemasy Recursors Forestales, 16(3): 267-276.

Rousu P., Rousu P. \& Anttila J. (2002). Sustainable Pulp Production from Agricultural Waste. Resources, Conservation and Recycling, 35: 85-103.

Sridach W. (2010). The environmentally benign pulping process of non-wood fibers. Suranaree Journal of Science and Technology, 17: 105-123.

Usta M. \& Eroglu H. (1987). Soda-Oxygen Pulping Rye Straw. In: Non-wood plant fibre conference. Washington DC. TAPPI press, progress report. No. 18, pp. 113-118.

Xu F., Zhong X.C., Sun R.C. \& Lu Q. (2006). Anatomy, ultrastructure and lignin distribution in cell wall of Caragana Korshinskii. Industrial Crops and Products, 24(2): 186-193. 